\title{
Forest Development over a Twenty-Year Chronosequence of Reforested Urban Sites
}

\author{
Kenton L. Sena ${ }^{1, * \mathbb{D}}$, Zachary J. Hackworth ${ }^{2} \mathbb{D}$ and John M. Lhotka ${ }^{2}$ \\ 1 Lewis Honors College, University of Kentucky, 1120 University Drive, Lexington, KY 40526, USA \\ 2 Department of Forestry and Natural Resources, University of Kentucky, 730 Rose Street, Lexington, \\ KY 40546, USA; Zachary.hackworth@uky.edu (Z.J.H.); john.lhotka@uky.edu (J.M.L.) \\ * Correspondence: Kenton.sena@uky.edu
}

Citation: Sena, K.L.; Hackworth, Z.J.; Lhotka, J.M. Forest Development over a Twenty-Year Chronosequence of Reforested Urban Sites. Forests 2021, 12, 614. https://doi.org/10.3390/ f12050614

Academic Editor: Bruce D. Clarkson

Received: 15 March 2021

Accepted: 6 May 2021

Published: 13 May 2021

Publisher's Note: MDPI stays neutral with regard to jurisdictional claims in published maps and institutional affiliations.

Copyright: (c) 2021 by the authors. Licensee MDPI, Basel, Switzerland. This article is an open access article distributed under the terms and conditions of the Creative Commons Attribution (CC BY) license (https:/ / creativecommons.org/licenses/by/ $4.0 /)$.

\begin{abstract}
Urbanization causes a variety of negative ecological impacts, impairing forests, streams, and other ecosystems. While urban forests are the subject of increasing research attention, planted urban forests are less well-understood than remnant forests; however, these systems may be distinct in terms of ecosystem structure and function. The current study investigates a chronosequence of reforested urban sites in Lexington, KY, USA, with a focus on overstory and understory woody plant community characteristics. Monitoring plots were established in each of the 20 sites; tree height, $\mathrm{dbh}$, and species were surveyed for the overstory, and species and height were surveyed for the understory. Canopy height increased non-linearly with time since planting, rapidly increasing in years $6-10$, but remaining relatively steady after year 15 . While the overstory was dominated by planted native species, the understory was predominately non-native species, some of which are considered invasive. Overall, the nonlinear logistic relationship of canopy height to time since planting may be driven by species-specific effects-with trees such as ash (Fraxinus spp. L.) and black locust (Robinia pseudoacacia L.) important during the early years after planting, but declining over time due to pests and other pressures. Alternatively, this complex relationship of canopy height with time may be driven by uncontrolled factors such as site quality, landscape position, planted species, etc. The significance of invasive species in the understory suggests that the long-term health of these sites will be compromised without intentional ongoing maintenance to ensure continued forest development toward desired native community characteristics.
\end{abstract}

Keywords: reforestation; forest ecology; forest restoration; urban and community forests; afforestation; urban ecology; invasive species; forest growth

\section{Introduction}

Urbanization drives significant and persistent ecological change, especially to forests. Urban and suburban development leads to forest loss and fragmentation throughout the urban and peri-urban area, as forest-land is converted into industrial, commercial, and residential space [1,2]. As tree cover decreases and impervious surfaces increase, the urban ecosystem experiences dramatic shifts in hydrology, with decreased interception and infiltration and increased stormwater runoff, driving extreme stream responses to rain events [3]. Furthermore, these shifts in landcover from vegetation to hardscape have been associated with elevated urban temperatures, an effect known as the urban heat island effect [4]. Urbanization is also associated with impaired soil health [5], water quality [6], and air quality [7]. In addition, urban ecosystems are vulnerable to non-native species invasions, with significant consequences to biodiversity at multiple spatial scales [8].

Despite the negative ecological effects of urbanization, urban forests, including remnant forest patches, parkland, woodlots, and street trees, perform remarkably important ecosystem services [9,10]. Moss et al. [11] found that evapotranspiration provided by urban forests in the United Kingdom reduced energy use for indoor climate control up to $13 \%$. Similarly, Nowak et al. [12] estimated that urban trees in the USA remove over 
700,000 metric tons of pollutants annually, including ozone, nitrous oxide, sulfur dioxide, carbon monoxide and particulate matter-an estimated saving of $\$ 3.8$ billion. With respect to regulating the urban water cycle, Kuehler et al. [13] highlight the importance of urban trees in increasing stormwater storage and retention and reducing stormwater runoff through increased interception, evapotranspiration, and infiltration. Urban forests also provide habitat for a suite of organisms which in turn perform their own ecosystem services [14,15]. Furthermore, as estimated by Nowak et al. [16], urban trees in the US represent a total carbon storage pool of over 640 million metric tons. Finally, urban forests provide critical aesthetic and recreation services, providing spaces for outdoor activities and increasing human-environment interactions [17,18].

Increasingly, urban reforestation seeks to restore forests in degraded urban sites. Kroeger et al. [19] highlight urban reforestation as a solution for ozone pollution, suggesting that planted urban forests can provide air quality improvement services. Similarly, Hession et al. [20] found that riparian reforestation increased stream-water nutrient levels (by shading out algae) and shifted macroinvertebrate community composition toward shredders (related to contribution of leaves). Kang et al. [21] documented bird use, and Smith and Gehrt [22] reported bat use of restored urban forests. Planted urban forests can also continue to develop over time, increasing in species diversity and vertical forest structure over time since restoration [23]. While planted urban forests provide significant ecosystem service benefits, some studies suggest that planted forests are less valuable than preserved remnant forests, raising questions about how to improve the ecological value of planted urban forests through management and maintenance. For example, while Kang et al. [21] found that birds use planted urban forests, they reported that remnant forests supported greater avian diversity than planted sites. In addition, planted urban forests are plagued by the same challenges as remnant forests, including high levels of human activity [21,24,25], and significant pressure from invasive species [22,23,26-31]. Thus, in addition to the continued work necessary to understand how best to manage remnant stands to preserve and improve their ecosystem service provisioning, research is necessary to understand how planted forests develop over time, with particular attention to controls on developmental trajectory and influence of initial and ongoing management activities.

However, development of urban planted forests over time has not been intensively studied. Pregitzer et al. [32] found that urban soils can inhibit native tree growth and health, which may present a significant barrier to long-term success of planted urban forests. In contrast, Oldfield et al. [33] found that compost addition at planting could improve growth of planted trees, suggesting that site preparation could ameliorate some unfavorable site conditions. A number of studies have reported significant effects of invasive plant species on long-term community development of planted urban forests, with invasive species often playing a significant role in remnant urban forests targeted for restoration plantings [34] and requiring ongoing management to ensure success of understory plantings [35,36]. Importantly, planted forests have also demonstrated natural regeneration of native species $[23,37]$ and can achieve structural conditions approaching those of remnant forests [38]. In their review, Oldfield et al. [39] called for long-term continuous vegetation monitoring to better understand forest successional development over time in afforested urban sites, as well as more studies investigating the long-term ecological effects of invasive species, and the long-term effects of site conditions on recruitment after initial planting.

The goal of this study is to contribute long-term data to the relatively sparse body of literature on urban forest growth by utilizing key metrics of forest stand development as benchmarks for determining long-term success of planted urban forests in Lexington, KY, USA. Specifically, this study utilizes a 20-year chronosequence of urban forest restoration plantings to (1) define forest structure and composition characteristics in relation to time since planting, (2) quantify rate and variation of stand development pathways as indicated by canopy height growth and aboveground biomass accumulation, and (3) explore the role of invasive species in shaping forest community formation. 


\section{Materials and Methods}

\subsection{Study Sites}

The study sites we assessed were a chronosequence of planted urban forest sites located in Lexington, KY, USA. The city of Lexington is a mid-sized US city, covering about 283 square miles with approximately 323,000 residents [40]. These sites were planted as part of a community urban reforestation program called Reforest the Bluegrass (RTB), given Lexington's location within the Inner Bluegrass physiographic region of Kentucky. According to the Lexington-Fayette Urban County Government (LFUCG [41]), the local governing body overseeing the program, Reforest the Bluegrass has engaged over 17,500 volunteers in planting more than 150,000 seedlings on over 190 acres since 1999, the first year of the program (Figure 1). A new site is planted as part of RTB each year; thus, 21 sites were available for surveying (one site per year) in Summer 2020.
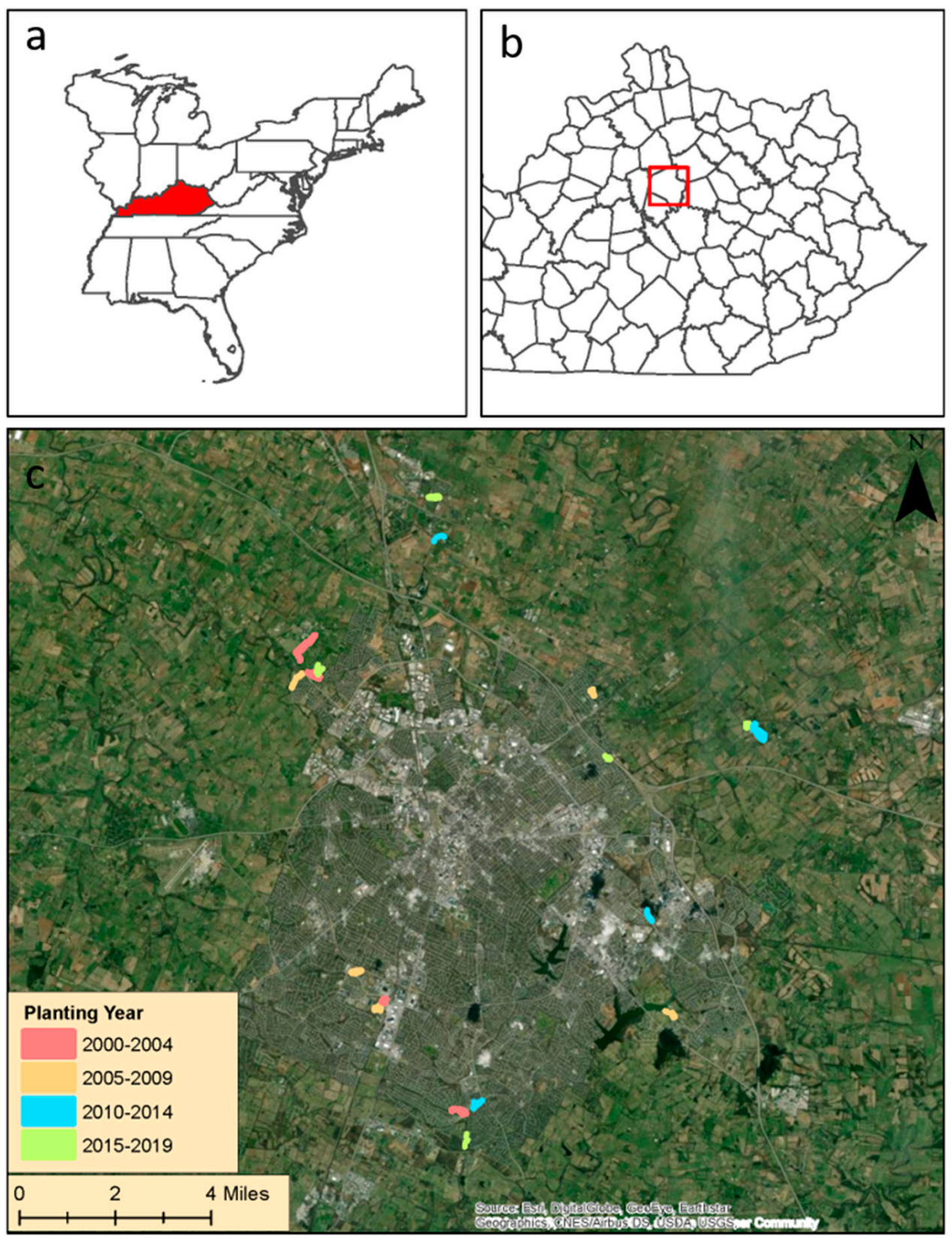

Figure 1. (a) Kentucky, USA. (b) Fayette County, Kentucky. (c) Location of Reforest the Bluegrass reforestation sites in Lexington, KY, USA. 
Prior to planting, most sites selected for reforestation were open land, historically cleared for agricultural use and eventually incorporated into the LFUCG Parks and Recreation system. While some planting sites had larger scattered remnant trees, most sites were continuously mowed prior to planting. Due to the program's interest in contributing to stormwater management and stream-water quality improvement, riparian and floodplain sites were usually prioritized for planting.

Planted tree seedlings were generally a mix of native species appropriate to the region, including a mix of upland and lowland species. The planting stock were nursery-grown bare-root tree seedlings typically grown in a nursery bed 1 or 2 growing seasons. While early plantings were sometimes arranged single-species blocks, with riparian species planted in blocks alongside streams and more upland species planted in blocks further away from streams, later plantings were mixed across the project area.

Volunteers led by experienced group leaders planted seedlings on a $4 \mathrm{ft} \times 4 \mathrm{ft}(1.2 \mathrm{~m}$ $\times 1.2 \mathrm{~m})$ or $6 \mathrm{ft} \times 6 \mathrm{ft}(1.8 \mathrm{~m} \times 1.8 \mathrm{~m})$ spacing (denoted by painted locations on the ground; planted spacings varied from year to year). Trees were planted by hand using a dibble bar or tree spade. Following planting, weed-barrier mats approximately $1 \mathrm{~m}$ wide were installed around the trees to minimize initial herbaceous competition.

\subsection{Survey Methods}

In the summer of 2020, digital site maps were prepared from hand-drawn maps provided by LFUCG personnel. Maps were digitized in ArcGIS 10.7 (ESRI, Redlands, CA, USA) by delineating the planted forest boundary visible on aerial imagery. After delineating planted forest patches, a $19.8 \mathrm{~m}(65 \mathrm{ft})$ inner buffer from the planted forest edge was applied using the buffer tool. Potential plot locations were visually assessed on printed site maps (with buffer from edge applied) as a guide. The first plot center at a given site was established within the buffered zone by pacing the target distance $(19.8 \mathrm{~m})$ from site edge. Subsequent plots were established by pacing the target distance $(19.8 \mathrm{~m})$ from previous plot(s) and maintaining the minimum distance from edge. Plots were also located to avoid overlap with stream channels or trails. (Note: in some cases, sites were narrow riparian or trailside plantings and were too narrow to avoid sampling within $19.8 \mathrm{~m}$ from the site edge. In these cases, plots were located as near as possible to the center of the planted area to minimize edge effects.) A minimum of three plots were established within each planting site; additional plots were established if sites were large enough to allow placement of additional plots far enough from other plots and plot edge (mean \pm SD: $4.6 \pm$ 2.5 plots; $\max =9)$. Plot centers were marked with a 1.5-m (5-ft) PVC stake, and geographic coordinates for each plot were recorded to facilitate continued monitoring.

At each plot, 0.008-ha (0.02-ac) and 0.002-ha (0.005-ac) circular sampling plots were established concentric on the plot center to survey woody overstory and understory species, respectively. Within each 0.008-ha overstory plot, the species, diameter at breast-height $(\mathrm{DBH})$, and total height of each tree $\geq 2.5 \mathrm{~cm}(1 \mathrm{in}) \mathrm{DBH}$ were recorded. $\mathrm{DBH}$ was measured to the nearest $0.25 \mathrm{~cm}(0.1 \mathrm{in})$ using a $\mathrm{DBH}$ tape, and tree height was measured to the nearest $0.1 \mathrm{~m}$ using a laser hypsometer (Nikon Forestry Pro II) or telescoping height pole. Within each 0.002-ha understory plot, height and species of all woody plants $<2.5 \mathrm{~cm} \mathrm{DBH}$ and $\geq 30 \mathrm{~cm}$ tall were tallied. Height of understory woody plants was measured to the nearest $0.5 \mathrm{~cm}$ with a telescoping height pole.

To help describe site conditions, soil samples were collected in each plot. Samples were composited from five subsamples collected from plot center and approximately $1 \mathrm{~m}$ from plot center in the four cardinal directions. Subsamples were collected to a depth of approximately $10 \mathrm{~cm}$ using a sampling spade. Composite samples were air dried and passed through a $2 \mathrm{~cm}$ sieve, then sent to the University of Kentucky regulatory services soils lab for analysis. Soils were analyzed for $\mathrm{pH}$ [42], P [43], K, Ca, Mg, Zn [44], mineral particle size class [45,46], total C [47], and total N (analyzed using a LECO combustion instrument). Soil characteristics were evaluated for significant relationships with years 
since planting using simple linear regression (PROC REG, SAS 9.4). Tree and soil data were collected in Summer 2020.

\subsection{Statistical Methods}

Given the site variation among planting locations, differences in planting implementation procedures during the early years of the RTB initiative, and the prevalence of relatively small areas selected for planting, descriptive statistics were preferred to summarize and evaluate the success of reforestation efforts across the 20-year chronosequence (2000-2019). (Due to unintentional mowing activity that occurred across the 1999 planting site since it was planted, data from this site were excluded.) All data analysis was performed using the R programming language [48].

For each site (representing each planting year), the plot-level basal area $\left(\mathrm{m}^{2} \mathrm{ha}^{-1}\right)$ and aboveground biomass ( $\mathrm{t} \mathrm{ha}^{-1}$ ) accumulation of overstory trees were calculated, as well as stem density (trees ha-1) and percentage of stems of non-native introduced species for overstory and understory trees. Aboveground biomass of each tree within a plot was estimated using the allometric equations presented in Chojnacky et al. [49]. To derive a site-level summary of these measures, the annual mean and standard error of each metric were calculated and their time-series trends were analyzed graphically. To evaluate stand structure and mortality patterns, the mean basal area and percentage of dead and declining stems by diameter classes $(2.5-5.0 \mathrm{~cm}$ and $5-\mathrm{cm}$ classes up to $40 \mathrm{~cm}$ ) for each of the six oldest sites (2000-2005) were calculated and each site was visualized graphically.

For each understory plot, the stem density and mean total height of woody reproduction (planted and colonizing) were calculated. To investigate regeneration trends, each stem was categorized as either a native or introduced species and mean total height of woody understory stems was calculated for each category within sites. Native species were further categorized by shade tolerance (i.e., intolerant, intermediate, and tolerant) and the mean percentage of stems within each category was calculated to evaluate compositional trends in woody regeneration across the chronosequence. The predominant architectural forms (shrub-forming vs. tree-forming) of introduced species were also examined by tabulating the mean percentage of introduced species by form type in overstory and understory positions within 5-year age-classes.

To evaluate height and compositional trends in the primary tree canopy, upper overstory height for each plot was calculated by averaging the heights of the tallest $25 \%$ of trees with $\mathrm{DBH} \geq 2.5 \mathrm{~cm}$ [50]. Trees in the upper overstory were categorized as being of either native or introduced origin, and the mean and standard error of the upper overstory height by category was calculated across sites. To infer the effect of stand development time on height growth, upper overstory height was evaluated in a regression framework, whereby mean plot-level upper canopy height was regressed by planting year. After initial data exploration, two regression models were considered to fit these data: (1) a logistic model fit using nonlinear least squares via a self-starting function in the R package "stats" [48] and (2) a third-degree (cubic) B-spline function fit via a call to the R package "splines" [48] within ordinary least squares linear regression. Regression assumptions of each model were evaluated and satisfied prior to model comparison. Model comparison was performed using Akaike's information criterion corrected for small sample size (AICc; R package "MuMIn" [51]) and root mean squared error (RMSE). The logistic model possessed a smaller AICc (506.0 versus 509.0) and RMSE (3.1 m versus $3.2 \mathrm{~m}$ ) than the spline model. Therefore, the logistic model was selected and analyzed as the final upper overstory height model. 


\section{Results}

\subsection{Overstory}

RTB plantings have experienced positive growth since 2000. Mean basal area of the oldest planting (20 years old) was $18.4 \pm 2.3 \mathrm{~m}^{2} \mathrm{ha}^{-1}$ (SE), and mean density of trees $\geq 2.5 \mathrm{~cm}$ DBH was $1215 \pm 293$ stems ha $^{-1}$. Upper canopy height (tallest $25 \%$ of trees) of the 20-year-old planting averaged $11.7 \pm 1.9 \mathrm{~m}$, with native hardwoods comprising all the overstory. Estimated per-hectare aboveground woody biomass of overstory trees in this site was $93.1 \pm 17.5 \mathrm{t}$. Data supporting analysis of the overstory community on these sites are available at Jacobs et al. [52].

Growth trajectories of area-wide basal area and aboveground tree biomass demonstrated a positive relationship with time since planting (Figure 2). Metrics typically increased slowly during the first 5 years after planting, with densities of stems $\geq 2.5 \mathrm{~cm} \mathrm{DBH}$ ranging 0 to 759 stems ha ${ }^{-1}$ in this period. Between, approximately, years 6 and 10, growth appeared nearly linear but plateaued after years 11-14, after which sites began to exhibit relatively homogeneous characteristics. Sites between ages 15 and 20 years had a mean basal area of $16.4 \pm 3.7 \mathrm{~m}^{2} \mathrm{ha}^{-1}$, much of which was concentrated in the $10-30 \mathrm{~cm} \mathrm{DBH}$ classes. Overstory conditions were highly variable in some sites, departing from the overall trends. In the 2007 site, areawide basal area and biomass were lower than expected, resulting from a combination of slower-growing species occupying the site (e.g., oaks [Quercus spp. L.] and boxelder [Acer negundo L.]) and the existence of apparent underdeveloped colonizing species (e.g., black locust). Exceptional conditions were also observed at sites planted in 2006, 2011, and 2017. Sites planted in 2006 possessed a high density of large trees that rapidly capture the overstory (e.g., American sycamore [Platanus occidentalis L.], black locust, and silver maple [Acer saccharinum L.], and yellow-poplar [Liriodendron tulipifera L.]). The 2011 planting yielded one plot with an extraordinary high density (62 stems in one overstory plot), resulting in an unusually high overstory density estimate. In the 2017 planting, one plot possessed several small black locusts with DBH barely above $2.5 \mathrm{~cm}$, resulting in the unusual overstory estimates for this period.

While the plot-level rate of dead and declining stems was relatively low in the oldest plantings, all trees in the largest DBH class $(30.1-35.0 \mathrm{~cm})$ and nearly half of basal area in the $25.1-30.0 \mathrm{~cm}$ were either dead or declining in the 20-year-old planting; $10-30 \%$ of the basal areas in the 10-30 cm DBH classes were dead or declining in some of the other plantings during this period (Figure 3). Dead and declining trees with $\mathrm{DBH} \geq 10 \mathrm{~cm}$ in this period were composed predominantly of ash and Callery pear (Pyrus calleryana Decne.). Biomass accumulation appeared to plateau after year 14, resulting in mean biomass of $82.4 \pm 18.8 \mathrm{t} \mathrm{ha}^{-1}$ during this period (Figure 2). Upper overstory height possessed a significant logistic relationship with time (Figure 4). The upper overstory height model identified a mean upper height asymptote at $12.5 \pm 0.5 \mathrm{~m}(\mathrm{t}=24.4, p<0.001)$, an inflection point at year $2012(\mathrm{t}=4321.0, p<0.001)$, and a scale parameter of $-1.6 \pm 0.4(\mathrm{t}=-4.4$, $p<0.001$ ).

Species composition of stems $\geq 2.5 \mathrm{~cm}$ DBH was dominated by native hardwoods. Among the upper canopy, a speciose mixture of native trees was present (species richness $=25$ ), but American sycamore, black locust, and boxelder were most prevalent, accounting for $42.2 \%$ of stems. Mean site-level percentages of introduced species among stems $\geq 2.5 \mathrm{~cm}$ DBH ranged from 0 to $24 \%$, with a maximum of $65.8 \%$ at year 8 (Figure 2). In the upper overstory, mean rate of introduced species decreased with plantation age, with years 20102014 exhibiting the largest mean rate at $16.8 \% \pm 8.1$; tree-forming species, including Callery pear and white mulberry (Morus alba L.), comprised the dominant architecture type of introduced species (Table 1). Large Amur honeysuckle (Lonicera maackii [Rupr.] Maxim.) stems were also observed in the upper overstory of a few older sites. 

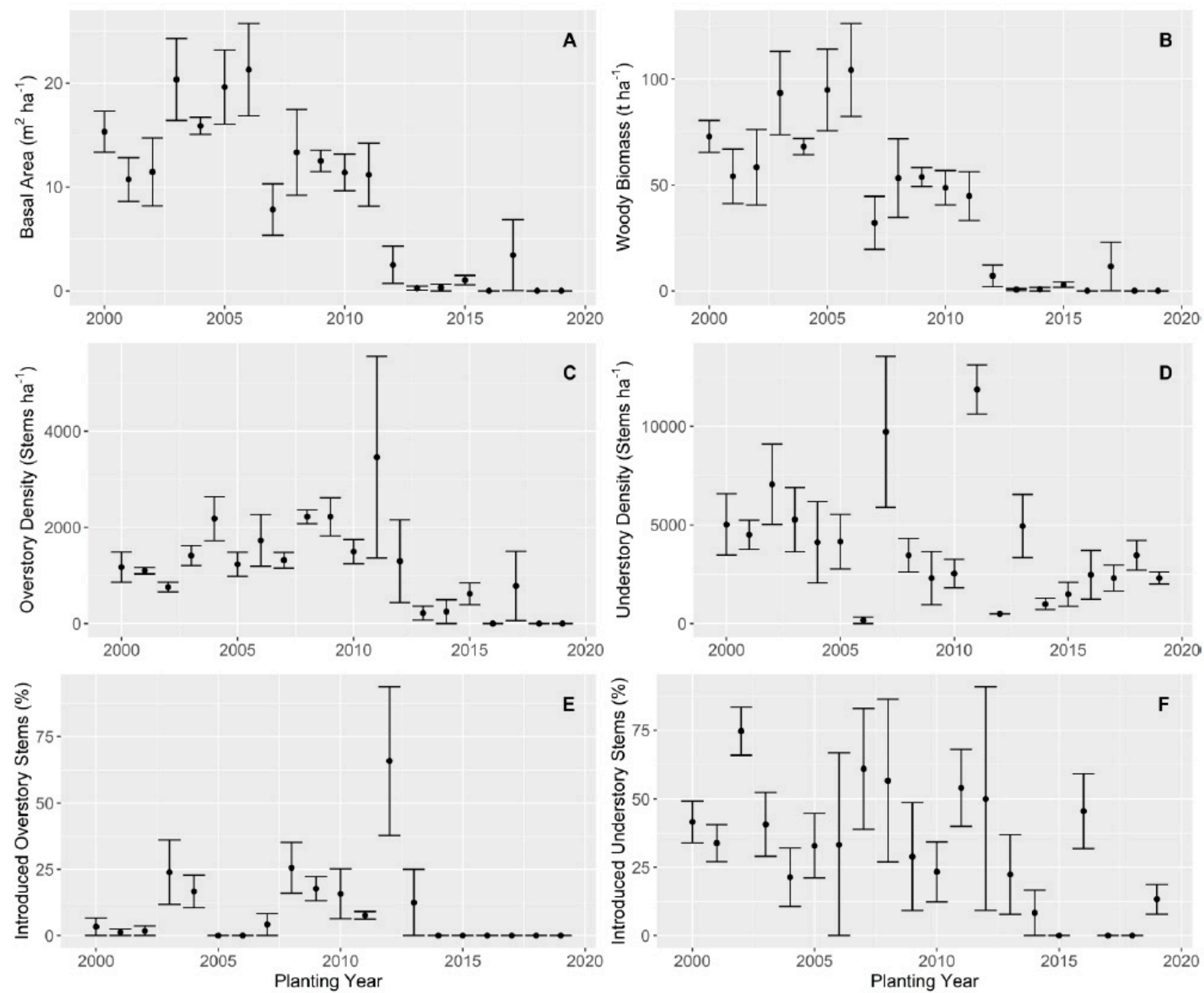

Figure 2. Annual summary statistics (mean $\pm \mathrm{SE}$ ) for (A) basal area, (B) woody biomass, (C) overstory $(\geq 2.5 \mathrm{~cm}$ DBH) density, (D) understory density, (E) percentage of introduced species in the overstory $(\geq 2.5 \mathrm{~cm} \mathrm{DBH})$, and (F) percentage of introduced species in the understory across the 20-year chronosequence of Reforest the Bluegrass sites in Lexington, KY, USA. Planting year (x-axis) represents the year when a given site was planted. Read from the left to the right, this ranges from the oldest site (20 years) to the newest site (1 year). 

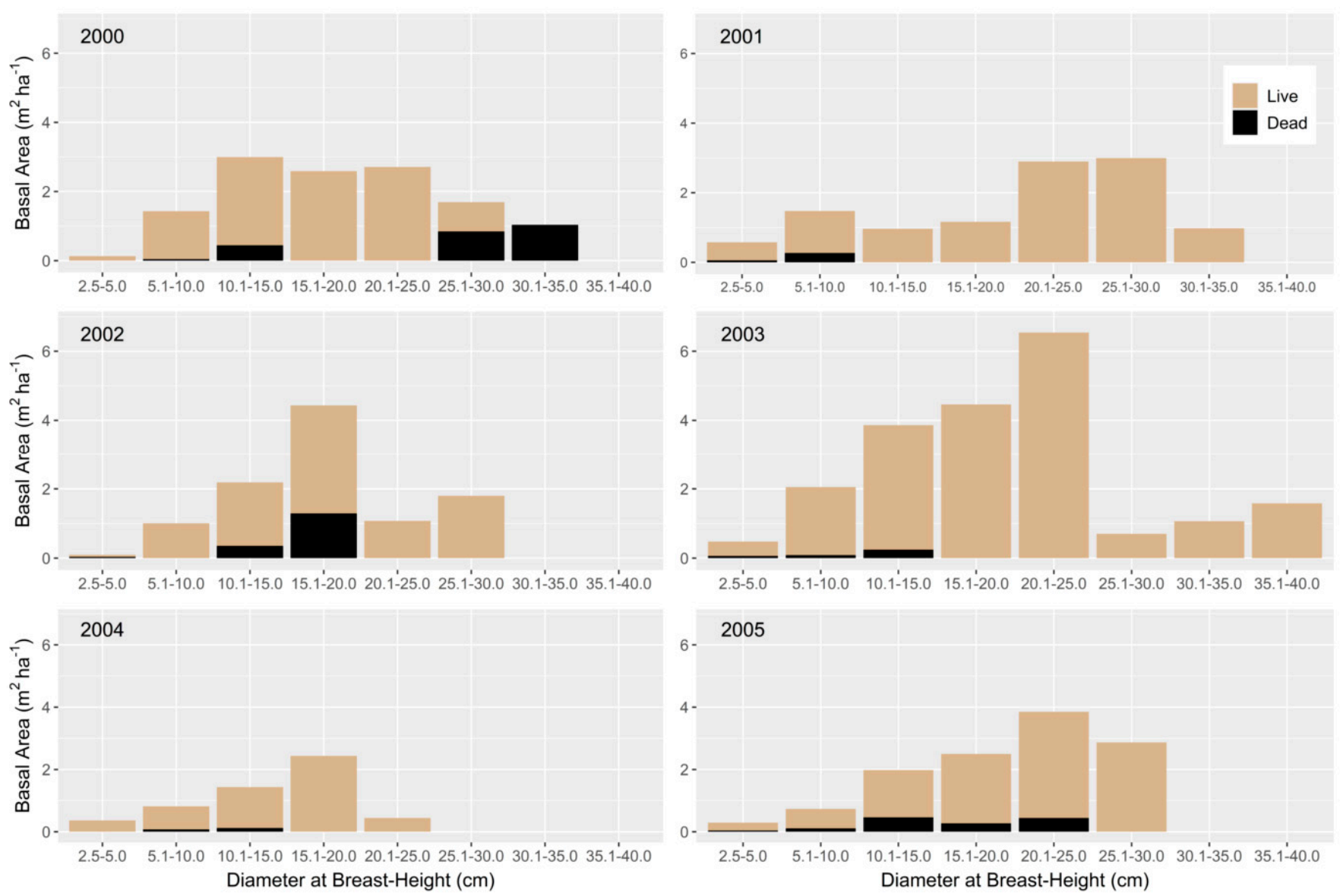

Figure 3. Mean basal areas of live and dead or declining trees by diameter classes in Reforest the Bluegrass sites planted in 2000-2005. Ash and Callery pear comprised the majority of dead and declining trees. 


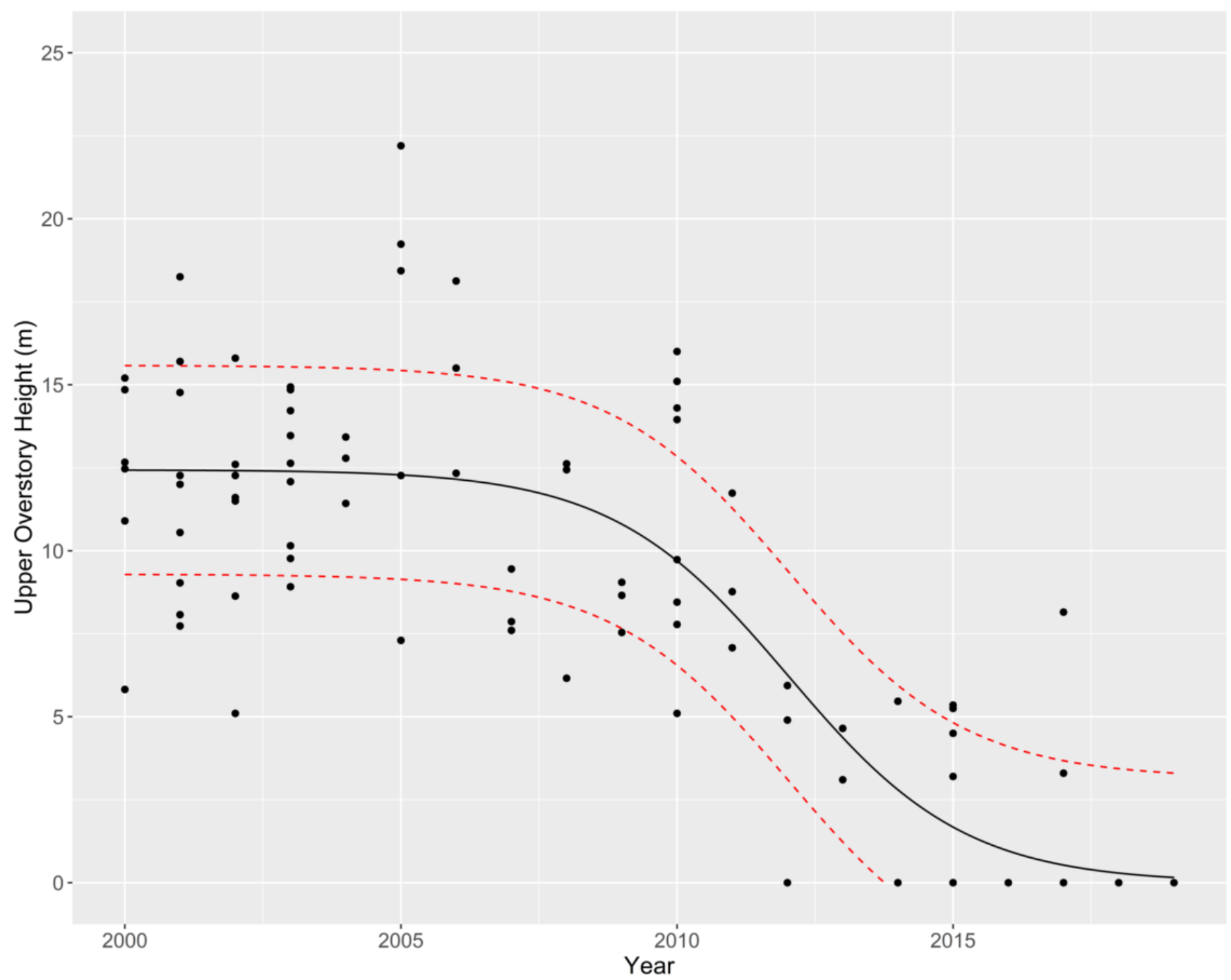

Figure 4. Plot-level mean heights of upper overstory trees (tallest $25 \%$ of trees with $\mathrm{DBH} \geq 2.5 \mathrm{~cm}$ ) by planting year, with predicted regression line of the nonlinear logistic model (black solid line) with root mean square error (RMSE; red dashed lines) in Reforest the Bluegrass sites in Lexington, KY, USA. Planting year (x-axis) represents the year when a given site was planted. Read from the left to the right, this ranges from the oldest site (20 years) to the newest site (1 year). Regression equation: Upper Overstory Height $=\frac{12.5}{1+\mathrm{e}^{-\frac{2012-Y e a r}{1.6}}}$.

Table 1. Relative composition (mean $\pm \mathrm{SE}$; \%) of introduced stems by architectural form across 5-year periods in the understory of Reforest the Bluegrass sites in Lexington, KY, USA.

\begin{tabular}{ccccccc}
\hline \multicolumn{3}{c}{ Overstory } & & \multicolumn{3}{c}{ Understory } \\
\hline Year & Shrub & Tree & Total & Shrub & Tree & Total \\
\hline $2000-2004$ & $1.5 \pm 1.5$ & $1.8 \pm 1.8$ & $3.2 \pm 2.2$ & $37.2 \pm 4.6$ & $8.5 \pm 3.0$ & $45.7 \pm 5.0$ \\
$2005-2009$ & 0 & $6.4 \pm 3.6$ & $6.4 \pm 3.6$ & $40.4 \pm 9.8$ & $6.5 \pm 2.6$ & $46.9 \pm 9.5$ \\
$2010-2014$ & $5 \pm 5$ & $11.8 \pm 6.9$ & $16.8 \pm 8.1$ & $21.1 \pm 6.5$ & $6.1 \pm 2.9$ & $27.2 \pm 7.1$ \\
$2015-2019$ & 0 & 0 & 0 & $6.2 \pm 3.7$ & $5.5 \pm 2.6$ & $11.7 \pm 4.2$ \\
\hline
\end{tabular}




\subsection{Understory}

High understory densities were present across nearly all sites, including both planted trees and colonizing reproduction. Density distributions displayed a trend where density decreased during this first 5-7 years after planting but increased thereafter before plateauing near year 15 (Figure 2); mean stem density for sites planted in 2000-2005 was $5021 \pm 450$ stems ha $^{-1}$. Mean understory height increased with forest age (Figure 5). While native hardwood species dominated the understory 10-12 years after planting, introduced species overtopped native species in older plantings (Figure 5). Introduced species accounted for $40 \%$ of understory stems across all sites, among which shrub-forming species, particularly Amur honeysuckle (Lonicera maackii [Rupr.] Herder), comprised the larger architecture type (Table 1). Tree-forming regeneration of introduced species was composed nearly exclusively of Callery pear. The rate of introduced species in the understory also increased with age but plateaued between 10 and 20 years after planting. High species richness was present among native reproduction (41 species) and was dominated by boxelder, common hackberry (Celtis occidentalis L.), and black locust, accounting for $29.9 \%$ of stems. Generally, shade intermediate and intolerant species were more abundant in the years immediately following planting but were gradually replaced by shade tolerant and introduced species (predominantly Amur honeysuckle, which is also shade tolerant) at 10-15 years after planting (Figure 6). Data supporting analysis of understory woody plants are available at Jacobs et al. [53].

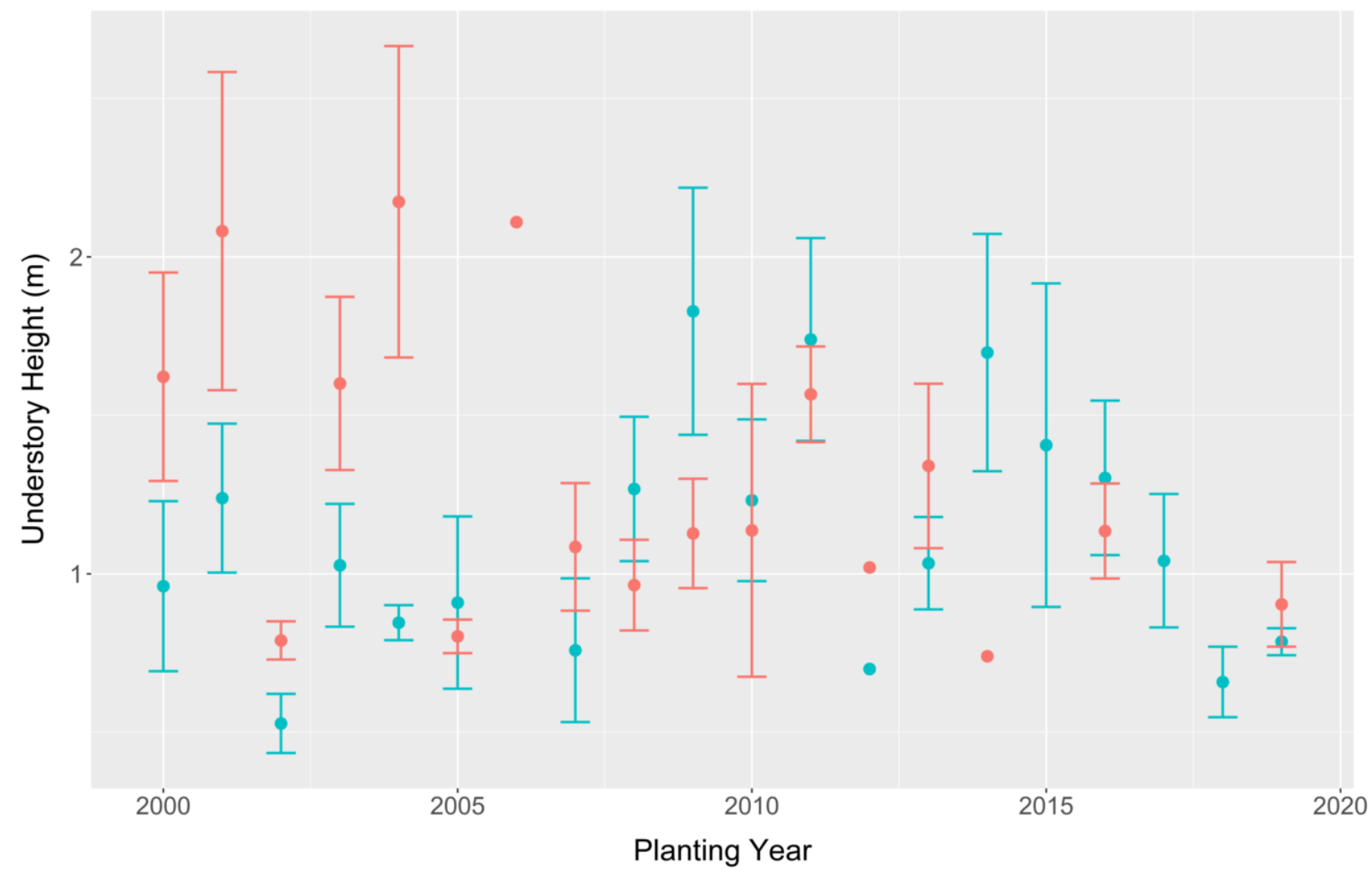

Figure 5. Height (mean $\pm \mathrm{SE}$ ) of native (blue lines) and introduced (red lines) species in the understory across the 20-year chronosequence of Reforest the Bluegrass plantings in Lexington, KY, USA. Planting year (x-axis) represents the year when a given site was planted. Read from the left to the right, this ranges from the oldest site (20 years) to the newest site (1 year). 


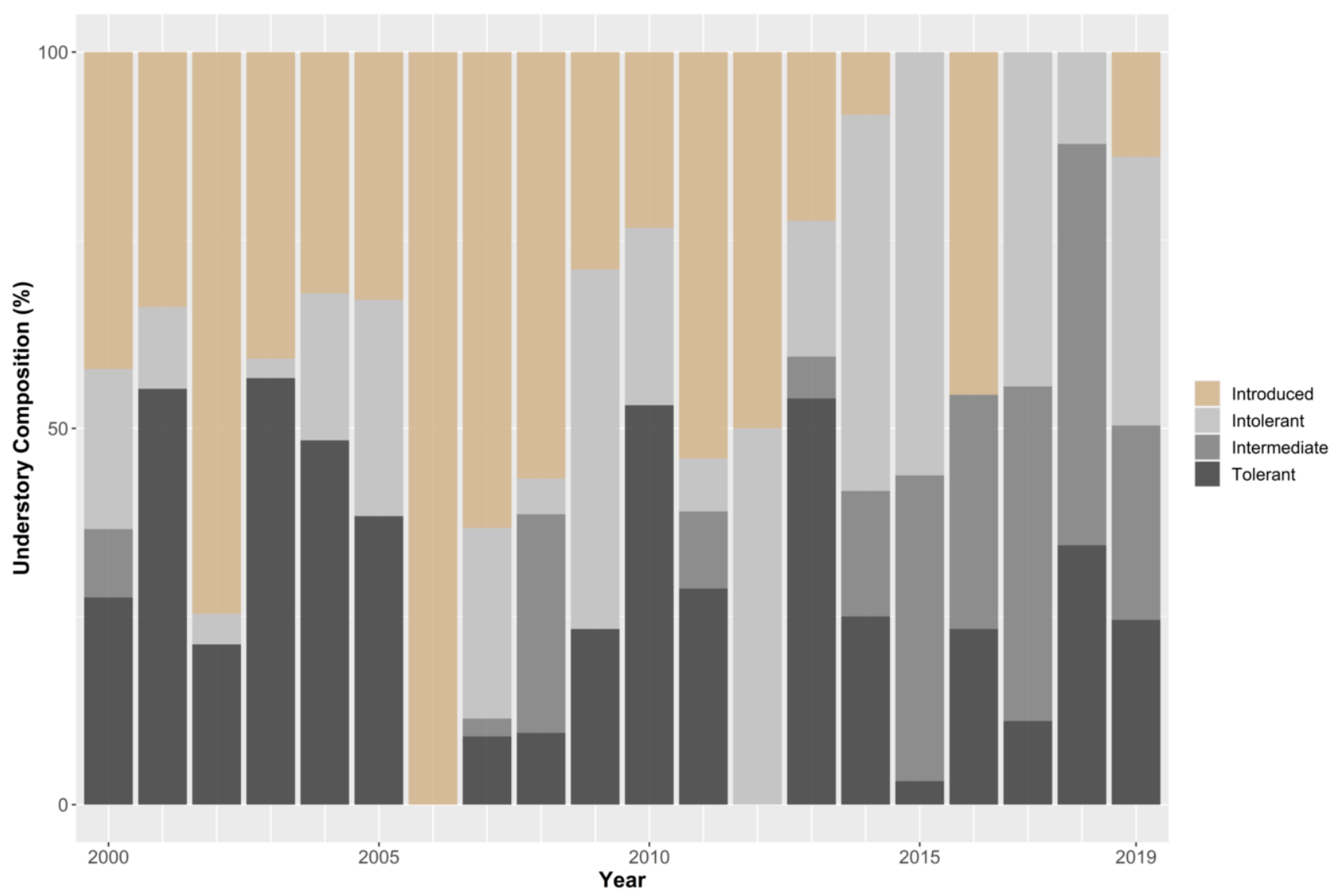

Figure 6. Mean percentage of understory stems in Reforest the Bluegrass sites by species category. Species were initially categorized as native or introduced species; native species were further delineated by shade tolerance class. Planting year (x-axis) represents the year when a given site was planted. Read from the left to the right, this ranges from the oldest site (20 years) to the newest site (1 year).

\subsection{Soils}

Summary soil data are presented in Table 2, and complete soils data are available at Jacobs et al. [54]. Of the measured soil characteristics, only P, Zn, and silt content were significantly related to years since reclamation $(p<0.05)$ and all slopes were positive. Phosphorus ranged from a minimum of $20 \mathrm{mg} / \mathrm{kg}$ in the 2014 planting site to a maximum of $316 \mathrm{mg} / \mathrm{kg}$ in the 2004 planting site and averaged $154 \mathrm{mg} / \mathrm{kg}$ across the sites. Zinc ranged from $1.38 \mathrm{mg} / \mathrm{kg}$ in the 2008 planting site to a maximum of $15.5 \mathrm{mg} / \mathrm{kg}$ in the 2001 site and averaged $5.43 \mathrm{mg} / \mathrm{kg}$ across sites. Finally, percent silt ranged between 58 and $75 \%$, while clay ranged from 10 to $21 \%$, and sand ranged from 11 to $21 \%$. Soil carbon exhibited no significant pattern with time and ranged from $1.5 \%$ in the 2016 site to $4.5 \%$ in the 2015 site. Mean soil $\mathrm{pH}$ ranged from a minimum of 4.36 in the 2008 site to a maximum of 6.78 in the 2018 site but also exhibited no consistent relationship with years since reclamation. 
Table 2. Chemical and physical characteristics of soils sampled from a 20-year chronosequence of reforested urban sites in Lexington, KY, USA (means \pm 1 SE).

\begin{tabular}{|c|c|c|c|c|c|c|c|c|c|c|c|}
\hline $\begin{array}{l}\text { Planting } \\
\text { Year }\end{array}$ & $\mathrm{pH}$ & P (mg/kg) & K (mg/kg) & Ca (mg/kg) & $\mathrm{Mg}(\mathrm{mg} / \mathrm{kg})$ & Zn (mg/kg) & Sand $(\%)$ & Silt (\%) & Clay (\%) & Total C (\%) & Total N (\%) \\
\hline 2000 & $5.41 \pm 0.33$ & $180.3 \pm 11.3$ & $109.3 \pm 13.5$ & $2791 \pm 479$ & $163.8 \pm 9.1$ & $3.45 \pm 0.38$ & $14.7 \pm 1.2$ & $74.8 \pm 1.4$ & $11.0 \pm 0.36$ & $3.8 \pm 0.11$ & $0.35 \pm 0.005$ \\
\hline 2001 & $4.94 \pm 0.27$ & $239.9 \pm 23.4$ & $174.6 \pm 15.6$ & $2665 \pm 428$ & $237.9 \pm 36.9$ & $15.5 \pm 10.9$ & $19.6 \pm 2.4$ & $67.0 \pm 3.9$ & $13.4 \pm 2.5$ & $3.95 \pm 0.36$ & $0.36 \pm 0.03$ \\
\hline 2003 & $6.49 \pm 0.13$ & $228.8 \pm 22.8$ & $142.0 \pm 30.8$ & $4196 \pm 217$ & $241.6 \pm 18.6$ & $12.6 \pm 2.58$ & $14.4 \pm 1.2$ & $70.0 \pm 1.2$ & $15.7 \pm 0.53$ & $3.73 \pm 0.16$ & $0.33 \pm 0.01$ \\
\hline 2004 & $5.93 \pm 0.34$ & $315.7 \pm 42.3$ & $180.0 \pm 31.1$ & $3589 \pm 246$ & $242.2 \pm 14.0$ & $4.15 \pm 0.55$ & $18.7 \pm 0.67$ & $65.3 \pm 1.4$ & $16.0 \pm 1.0$ & $3.73 \pm 0.30$ & $0.34 \pm 0.03$ \\
\hline 2005 & $6.43 \pm 0.11$ & $142.0 \pm 3.4$ & $80.3 \pm 4.8$ & $3973 \pm 290$ & $188.5 \pm 22.9$ & $12.6 \pm 5.63$ & $16.4 \pm 1.2$ & $70.0 \pm 1.4$ & $13.4 \pm 0.68$ & $3.45 \pm 0.22$ & $0.29 \pm 0.02$ \\
\hline 2006 & $6.58 \pm 0.10$ & $157.2 \pm 5.0$ & $87.3 \pm 12.6$ & $4444 \pm 74.7$ & $190.2 \pm 23.2$ & $11.2 \pm 3.4$ & $11.0 \pm 0.58$ & $73.7 \pm 0.33$ & $15.7 \pm 0.67$ & $3.56 \pm 0.19$ & $0.30 \pm 0.02$ \\
\hline 2008 & $4.36 \pm 0.24$ & $76.8 \pm 14.4$ & $65.0 \pm 16.9$ & $1248 \pm 213$ & $104.3 \pm 17.9$ & $1.38 \pm 0.19$ & $14.7 \pm 0.88$ & $75.3 \pm 1.8$ & $10.3 \pm 0.88$ & $2.70 \pm 0.18$ & $0.25 \pm 0.02$ \\
\hline 2009 & $6.10 \pm 0.38$ & $108.5 \pm 11.5$ & $156.5 \pm 52.5$ & $2837 \pm 421$ & $184.5 \pm 8.8$ & $7.62 \pm 0.22$ & $20.7 \pm 2.0$ & $65.3 \pm 2.7$ & $13.7 \pm 3.5$ & $3.22 \pm 0.44$ & $0.29 \pm 0.05$ \\
\hline 2010 & $6.36 \pm 0.28$ & $204.9 \pm 11.2$ & $126.9 \pm 23.7$ & $4376 \pm 358$ & $306.2 \pm 28.5$ & $5.31 \pm 1.05$ & $15.8 \pm 0.92$ & $67.1 \pm 1.3$ & $17.0 \pm 0.71$ & $4.08 \pm 0.19$ & $0.37 \pm 0.02$ \\
\hline 2011 & $5.25 \pm 0.32$ & $58.0 \pm 11.3$ & $143.5 \pm 25.7$ & $2575 \pm 442$ & $217.2 \pm 16.0$ & $3.65 \pm 0.21$ & $12.3 \pm 0.88$ & $73.0 \pm 3.0$ & $15.3 \pm 3.38$ & $3.42 \pm 0.03$ & $0.31 \pm 0.01$ \\
\hline 2012 & $6.33 \pm 0.32$ & $168.0 \pm 4.4$ & $181.2 \pm 67.4$ & $3645 \pm 446$ & $174.2 \pm 31.8$ & $6.35 \pm 2.49$ & $18.3 \pm 2.9$ & $65.0 \pm 2.9$ & $16.3 \pm 0.33$ & $3.52 \pm 0.23$ & $0.32 \pm 0.03$ \\
\hline 2013 & $5.33 \pm 0.15$ & $55.3 \pm 11.4$ & $252.8 \pm 13.4$ & $2710 \pm 144$ & $258.1 \pm 11.6$ & $3.84 \pm 0.66$ & $15.8 \pm 0.85$ & $69.5 \pm 1.3$ & $15.8 \pm 1.4$ & $4.25 \pm 0.28$ & $0.39 \pm 0.02$ \\
\hline 2014 & $4.64 \pm 0.08$ & $20.3 \pm 2.5$ & $77.6 \pm 5.6$ & $1727 \pm 133$ & $219.5 \pm 14.8$ & $1.75 \pm 0.26$ & $21.0 \pm 0.58$ & $67.2 \pm 0.85$ & $12.0 \pm 0.41$ & $3.76 \pm 0.19$ & $0.37 \pm 0.02$ \\
\hline 2015 & $5.91 \pm 0.26$ & $189.5 \pm 8.4$ & $119.0 \pm 24.9$ & $3739 \pm 295$ & $163.1 \pm 10.4$ & $3.22 \pm 0.35$ & $20.7 \pm 2.3$ & $67.3 \pm 2.2$ & $11.8 \pm 0.65$ & $4.47 \pm 0.24$ & $0.44 \pm 0.02$ \\
\hline 2016 & $5.60 \pm 0.22$ & $265.5 \pm 11.1$ & $98.2 \pm 5.2$ & $3181 \pm 347$ & $124.8 \pm 6.1$ & $1.63 \pm 0.26$ & $20.7 \pm 0.67$ & $58.0 \pm 1.2$ & $21.3 \pm 0.67$ & $1.48 \pm 0.06$ & $0.14 \pm 0.01$ \\
\hline 2018 & $6.78 \pm 0.21$ & $241.3 \pm 49.1$ & $205.8 \pm 64.8$ & $5774 \pm 748$ & $267.5 \pm 46.8$ & $4.05 \pm 1.66$ & $19.0 \pm 0.58$ & $59.3 \pm 3.5$ & $21.0 \pm 3.6$ & $3.50 \pm 0.49$ & $0.25 \pm 0.07$ \\
\hline 2019 & $4.64 \pm 0.09$ & $121.1 \pm 11.7$ & $168.0 \pm 19.6$ & $1600 \pm 108$ & $190.4 \pm 5.4$ & $2.52 \pm 0.32$ & $14.7 \pm 0.50$ & $71.0 \pm 1.0$ & $14.6 \pm 0.97$ & $2.94 \pm 0.11$ & $0.30 \pm 0.01$ \\
\hline Maximum & 6.78 & 315.67 & 287.50 & 5774.50 & 306.25 & 15.53 & 0.210 & 0.753 & 0.213 & 0.045 & 0.004 \\
\hline Minimum & 4.36 & 20.25 & 65.00 & 1247.84 & 104.33 & 1.38 & 0.110 & 0.580 & 0.103 & 0.015 & 0.001 \\
\hline Mean & 5.66 & 154.44 & 150.20 & 3148.21 & 207.40 & 5.43 & 0.165 & 0.681 & 0.154 & 0.035 & 0.003 \\
\hline \multicolumn{12}{|c|}{ Regression Statistics † } \\
\hline Slope & 0.023 & 7.704 & -0.706 & 43.5 & 0.768 & 0.844 & -0.001 & 0.002 & -0.001 & 0.000 & -0.000 \\
\hline$p$-value & 0.096 & 0.004 & 0.769 & 0.285 & 0.729 & 0.019 & 0.204 & 0.037 & 0.090 & 0.338 & 0.864 \\
\hline $\mathrm{R}^{2}$ & 0.019 & 0.086 & 0.001 & 0.002 & 0.001 & 0.057 & 0.017 & 0.045 & 0.030 & 0.010 & 0.000 \\
\hline
\end{tabular}

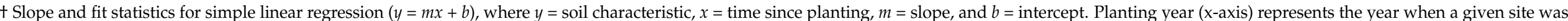
planted. Read from the top to the bottom, this ranges from the oldest site (20 years) to the newest site (1 year). Bold regression statistics indicate $p<0.05$. 


\section{Discussion}

This project represents one of the first chronosequence studies of reforested urban sites and, thus, presents important data for understanding forest growth and development on such sites. In our surveys, planted trees successfully established a closed canopy 7-9 years after planting, with mean upper canopy height exceeding $11 \mathrm{~m}$ and aboveground woody biomass exceeding 90 metric tons ha- 1 in the 20 -year site.

Upper canopy height growth exhibits an interesting and unexpected relationship with time since planting. Developing forests in other contexts tend to exhibit continued height growth over time since establishment [55-57]; however, our model of upper canopy height demonstrates a logistic relationship, with height growth mostly flat in sites planted in 2000-2006. We suggest that this relationship is related to two important processes ongoing in these sites. First, planted trees at older sites included large numbers of green and white ash, which were commonly planted in urban trees and abundant in forests in the Inner Bluegrass region prior to the widespread establishment of the Emerald Ash Borer (Agrilus planipennis [58]) after approximately 2010. Our surveys noted that ash trees were declining or dead throughout sites where they were planted, exhibiting symptoms associated with ash borer infestation. Ash is known to be a strong competitor on reforestation sites $[59,60]$ and based upon crown positions observed in this study this species group represented the leading edge of canopy height growth in these sites. However, as ash borer infestations progressed and ash trees began to decline and die, overall canopy height growth would have dampened for this species group. Similarly, a number of early successional trees, such as black locust and boxelder, were commonly planted in these sites. Black locust is an early successional tree frequently used in reclamation plantings in degraded sites for its role in nitrogen fixation; however, it is prone to disease and pest infestations and often does not persist in the canopy [60]. Boxelder is not typically a canopy tree in this region [60], and its height growth may also be slowing in the older planted sites. We posit that a combination of ash and black locust decline, as well as slowed height growth by boxelder and other midstory trees, are responsible for the observed upper canopy height pattern in older study sites. Continued monitoring on these sites will be necessary to characterize whether canopy height begins to increase again in older sites once trees more typical of the canopy in this region (e.g., oaks) become more important in the overstory.

Alternatively, the complex relationship of upper canopy height with time since planting could also demonstrate uncontrolled variability introduced by differences in preplanting site conditions, planted species, landscape context, and volunteer planting. Preplanting site conditions varied across sites, representing various pre-planting landscape positions including riparian sites on perennial and intermittent streams, retention basins, and sideslope drains. Planted species, while generally similar, also exhibited some variability across sites. Furthermore, the fact that these sites were planted as part of volunteer efforts introduces additional within-site variability related to planting skill. For example, one volunteer group could include experienced tree planters, while another group could include inexperienced planters-survival of planted trees could vary widely between these groups. It was difficult to incorporate these variables in our current analysis because not all pre-planting site data and species lists are presently available. Finally, our experimental and analytical approach was constrained by site availability. Planted sites were not blocked by year-even when multiple areas within a single park were planted, these plantings were located in discrete locations within the park, not blocked. Site availability thus forestalls our ability to employ more sophisticated analytical techniques sensitive to site differences. The chronosequence analytical approach was considered the most appropriate analytical approach, given these limitations. However, it is essential to note that these uncontrolled sources of variability likely contribute to the complex pattern of stand characteristics over time since planting, and present grounds for further research to clarify these potential sources of variability.

In addition to documenting the establishment of a diverse overstory over time, our study documents an important and disconcerting trend in understory community devel- 
opment: dominance by invasive species. While the overstory is dominated by native species in all sites (invasive species represent $>25 \%$ of overstory stems in only one site and $>12.5 \%$ of overstory stems in 6 sites), the understory is dominated by invasive species (invasive species represent $>25 \%$ of understory stems in 12 sites). Invasive species become established in sites within the first few years after planting and quickly increase in importance: 11 of the 13 sites planted before 2013 have significant invasive species presence in the understory. These observations are consistent with the urban forestry literature, which documents invasive species as a pervasive problem [8,23]. Our study suggests that invasive species become increasingly prevalent in the understory over time since planting, demonstrating that these species will be a persistent issue in the long-term stand development of the study sites.

Unlike monocultures typically established as part of commercial forestry plantations, the reforestation efforts outline by our study resulted in diverse forest stands through the mixture of native hardwood trees planted and natural tree colonization following planting. Large-scale forest restoration efforts have underscored the importance of mixed species plantations in the context of forest diversity and because planting an array of species with a range of ecological traits can help address the effects of variation in soil and hydrologic characteristics on reforestation success especially for riparian and floodplain sites [61]. Beyond the need for practitioners to match site-species relationships when designing restorative tree plantings, appropriate site preparation regimes before and after planting to control unwanted, competing vegetation have been shown to be an important component of success [62]. The site preparation approach utilized within the study chronosequence was mowing prior to planting and the use of 1-m-wide weed-barrier mats following planting. Based upon the evaluation of site preparation efficacy in other conservation tree plantings within the region, the use of chemical competition control during initial years following planting could have increased survival, improved initial growth rates, and enhanced competitive position of desired species across the study sites $[59,63]$. While such intensive early competition control treatments were not feasible within the reforestation program we studied, land management professionals should consider site preparation regimes as important tools for reforestation success, especially when sites are under pressure from colonization by invasive trees and shrubs. Best management practices for already established plantings may include proactive invasive species removal followed by enrichment planting with appropriate native trees and shrubs, coupled with long-term monitoring. LFUCG recently launched an ambitious urban forest health program targeting Reforest the Bluegrass sites, emphasizing invasive species removal and native species underplanting. Continued monitoring of these sites will be necessary to document the effectiveness of these practices and continue to characterize forest development over time.

\section{Conclusions}

Urban forests can provide critical ecosystem services, but patterns of urban forest development over time remain relatively unknown. The current study elucidates dimensions of woody plant community development across a chronosequence of planted urban forest sites in Lexington, KY, USA. Importantly, this study demonstrates that planted trees grow rapidly and establish a mostly native overstory. However, the logistic canopy height growth pattern observed in this study presents an unexpected and somewhat disconcerting picture of forest development. We suggest that this pattern is related to species-specific effects, with species on the leading edge of early height growth reaching maximum height or declining due to pests and other factors. Canopy height on these sites may be expected to resume a more linear growth pattern after species typical of the canopy in this region (e.g., oaks) are recruited into the canopy; however, further surveys will be necessary to characterize the timeframe of this succession. Alternatively, this complex relationship of canopy height with time since planting could be related to uncontrolled variability contributed by site conditions, landscape context, volunteer activity, and planted species. Additional surveys of these sites over time will support estimation of growth rates, increasing the 
sensitivity of these analyses. Furthermore, while planted native species were dominant in the overstory on these sites, invasive species are increasingly dominant in the understory. The importance of these undesirable and problematic species in the understory presents a concerning trend of future forests on these sites. Management for invasive species has already begun on some sites, and continued management will be necessary to ensure continued forest development toward ecosystem structure typical of healthy forests in this region. Furthermore, management should include targeted underplanting of native species typical of the region's mature climax forests, such as oaks and hickories.

Author Contributions: Conceptualization, K.L.S. and J.M.L.; Data curation, K.L.S. and Z.J.H.; Formal analysis, Z.J.H.; Funding acquisition, K.L.S. and J.M.L.; Investigation, K.L.S. and Z.J.H.; Methodology, K.L.S., Z.J.H. and J.M.L.; Project administration, K.L.S.; Resources, K.L.S. and J.M.L.; Software, Z.J.H.; Supervision, K.L.S. and J.M.L.; Validation, Z.J.H.; Visualization, Z.J.H.; Writing-original draft, K.L.S. and Z.J.H.; Writing-review and editing, K.L.S., Z.J.H. and J.M.L. All authors have read and agreed to the published version of the manuscript.

Funding: Research was funded by a University of Kentucky Sustainability Challenge Grant, which is a collaborative effort of the President's Sustainability Advisory Committee, the Tracy Farmer Institute for Sustainability and the Environment, and the Office of Sustainability. APC funded by Sena's Storkan-Hanes-McCaslin Award.

Data Availability Statement: The data presented in this study are openly available in the Environmental Data Initiative repository at https:/ / doi.org/10.6073/pasta/f22406ee858daeb0b8bf3e6f4 ed2ba00 (accessed on: 19 March 2021), reference number [52], https://doi.org/10.6073/pasta/ fdcb15813501becc1ce898972a19378a (accessed on: 16 April 2021), reference number [53], and https:/ / doi.org/10.6073/pasta/247c204871488a6ba981386fc3731559 (accessed on: 16 April 2021), reference number [54].

Acknowledgments: The authors gratefully acknowledge the assistance of Heather Wilson and John Saylor, Lexington Fayette Urban County Government, in providing site access and initiating the project. The authors also acknowledge invaluable field and data assistance provided by Kiernan Comer, Sabrina Jacobs, Kailey Jensen, Julia Maugans, and William Wittenbraker.

Conflicts of Interest: The authors declare no conflict of interest.

\section{References}

1. Miller, M.D. The impacts of Atlanta's urban sprawl on forest cover and fragmentation. Appl. Geogr. 2012, 34, 171-179. [CrossRef]

2. Zipperer, W.C.; Foresman, T.W.; Walker, S.P.; Daniel, C.T. Ecological consequences of fragmentation and deforestation in an urban landscape: A case study. Urban Ecosyst. 2012, 15, 533-544. [CrossRef]

3. Walsh, C.J.; Roy, A.H.; Feminella, J.W.; Cottingham, P.D. The urban stream syndrome: Current knowledge and the search for a cure. J. N. Am. Benthol. Soc. 2005, 24, 706-723. [CrossRef]

4. Rizwan, A.M.; Dennis, L.Y.; Chunho, L.I.U. A review on the generation, determination and mitigation of Urban Heat Island. J. Environ. Sci. 2008, 20, 120-128. [CrossRef]

5. Scharenbroch, B.C.; Lloyd, J.E.; Johnson-Maynard, J.L. Distinguishing urban soils with physical, chemical, and biological properties. Pedobiologia 2005, 49, 283-296. [CrossRef]

6. Wu, J.; Stewart, T.W.; Thompson, J.R.; Kolka, R.K.; Franz, K.J. Watershed features and stream water quality: Gaining insight through path analysis in a Midwest urban landscape, USA. Landsc. Urban Plan. 2015, 143, 219-229. [CrossRef]

7. Stone, B., Jr. Urban sprawl and air quality in large US cities. J. Environ. Manag. 2008, 86, 688-698. [CrossRef] [PubMed]

8. Shochat, E.; Lerman, S.B.; Anderies, J.M.; Warren, P.S.; Faeth, S.H.; Nilon, C.H. Invasion, Competition, and Biodiversity Loss in Urban Ecosystems. BioScience 2010, 60, 199-208. [CrossRef]

9. Nowak, D.J.; Crane, D.E.; Stevens, J.C.; Hoehn, R.E.; Walton, J.T.; Bond, J. A ground-based method of assessing urban forest structure and ecosystem services. Aboricult. Urban For. 2008, 34, 347-358.

10. Livesley, S.J.; McPherson, E.G.; Calfapietra, C. The Urban Forest and Ecosystem Services: Impacts on Urban Water, Heat, and Pollution Cycles at the Tree, Street, and City Scale. J. Environ. Qual. 2016, 45, 119-124. [CrossRef] [PubMed]

11. Moss, J.L.; Doick, K.J.; Smith, S.; Shahrestani, M. Influence of evaporative cooling by urban forests on cooling demand in cities. Urban For. Urban Green. 2019, 37, 65-73. [CrossRef]

12. Nowak, D.J.; Crane, D.E.; Stevens, J.C. Air pollution removal by urban trees and shrubs in the United States. Urban For. Urban Green. 2006, 4, 115-123. [CrossRef]

13. Kuehler, E.; Hathaway, J.; Tirpak, A. Quantifying the benefits of urban forest systems as a component of the green infrastructure stormwater treatment network. Ecohydrology 2017, 10, e1813. [CrossRef] 
14. Magle, S.B.; Hunt, V.M.; Vernon, M.; Crooks, K.R. Urban wildlife research: Past, present, and future. Biol. Conserv. 2012, 155, 23-32. [CrossRef]

15. Soulsbury, C.D.; White, P.C.L. Human-wildlife interactions in urban areas: A review of conflicts, benefits and opportunities. Wildl. Res. 2015, 42, 541-553. [CrossRef]

16. Nowak, D.J.; Greenfield, E.J.; Hoehn, R.E.; Lapoint, E. Carbon storage and sequestration by trees in urban and community areas of the United States. Environ. Pollut. 2013, 178, 229-236. [CrossRef]

17. Arnberger, A. Recreation use of urban forests: An inter-area comparison. Urban For. Urban Green. 2006, 4, 135-144. [CrossRef]

18. Soga, M.; Gaston, K.J. Extinction of experience: The loss of human-nature interactions. Front. Ecol. Environ. 2016, 14, 94-101. [CrossRef]

19. Kroeger, T.; Escobedo, F.J.; Hernandez, J.L.; Varela, S.; Delphin, S.; Fisher, J.R.B.; Waldron, J. Reforestation as a novel abatement and compliance measure for ground-level ozone. Proc. Natl. Acad. Sci. USA 2014, 111, E4204-E4213. [CrossRef] [PubMed]

20. Hession, W.; Johnson, T.; Charles, D.; Hart, D.; Horwitz, R.; Kreeger, D.; Pizzuto, J.; Velinsky, D.; Newbold, J.; Cianfrani, C.; et al. Ecological Benefits of Riparian Reforestation in Urban Watersheds: Study Design and Preliminary Results. Environ. Monit. Assess. 2000, 63, 211-222. [CrossRef]

21. Kang, W.; Minor, E.S.; Park, C.-R.; Lee, D. Effects of habitat structure, human disturbance, and habitat connectivity on urban forest bird communities. Urban Ecosyst. 2015, 18, 857-870. [CrossRef]

22. Smith, D.A.; Gehrt, S.D. Bat Response to Woodland Restoration within Urban Forest Fragments. Restor. Ecol. 2009, 18, 914-923. [CrossRef]

23. Simmons, B.L.; Hallett, R.A.; Sonti, N.F.; Auyeung, D.S.N.; Lu, J.W.T. Long-term outcomes of forest restoration in an urban park. Restor. Ecol. 2016, 24, 109-118. [CrossRef]

24. Dreistadt, S.H.; Donald, L.D.; Gordon, W.F. Urban Forests and Insect Ecology. BioScience 1990, 40, 192. [CrossRef]

25. DiCicco, J.M. Long-Term Urban Park Ecological Restoration: A Case Study of Prospect Park, Brooklyn, New York. Ecol. Restor. 2014, 32, 314-326. [CrossRef]

26. Hobbs, E.R. Species richness of urban forest patches and implications for urban landscape diversity. Landsc. Ecol. 1988, 1, 141-152. [CrossRef]

27. Overdyck, E.; Clarkson, B.D. Seed rain and soil seed banks limit native regeneration within urban forest restoration plantings in Hamilton City, New Zealand. N. Z. J. Ecol. 2012, 36, 177-190.

28. Farmer, S.; Ward, J.; Horton, J.; Clarke, D. Southern Appalachian urban forest response to three invasive plant removal treatments. Manag. Biol. Invasions 2016, 7, 329-342. [CrossRef]

29. Sjöman, H.; Morgenroth, J.; Sjöman, J.D.; Sæbø, A.; Kowarik, I. Diversification of the urban forest-Can we afford to exclude exotic tree species? Urban For. Urban Green. 2016, 18, 237-241. [CrossRef]

30. Archibald, C.L.; McKinney, M.; Mustin, K.; Shanahan, D.F.; Possingham, H.P. Assessing the impact of revegetation and weed control on urban sensitive bird species. Ecol. Evol. 2017, 7, 4200-4208. [CrossRef]

31. Clements, H.; Bierzychudek, P. Can the Persistent Seed Bank Contribute to the Passive Restoration of Urban Forest Fragments After Invasive Species Removal? Ecol. Restor. 2017, 35, 156-166. [CrossRef]

32. Pregitzer, C.C.; Sonti, N.F.; Hallett, R.A. Variability in Urban Soils Influences the Health and Growth of Native Tree Seedlings. Ecol. Restor. 2016, 34, 106-116. [CrossRef]

33. Oldfield, E.E.; Felson, A.J.; Auyeung, D.S.N.; Crowther, T.W.; Sonti, N.F.; Harada, Y.; Maynard, D.S.; Sokol, N.W.; Ashton, M.S.; Ii, R.J.W.; et al. Growing the urban forest: Tree performance in response to biotic and abiotic land management. Restor. Ecol. 2015, 23, 707-718. [CrossRef]

34. McPhearson, P.T.; Feller, M.; Felson, A.; Karty, R.; Lu, J.W.; Palmer, M.I.; Wenskus, T. Assessing the Effects of the Urban Forest Restoration Effort of MillionTreesNYC on the Structure and Functioning of New York City Ecosystems. Cities Environ. 2010, 3, 7. [CrossRef]

35. Johnson, L.R.; Handel, S.N. Restoration treatments in urban park forests drive long-term changes in vegetation trajectories. Ecol. Appl. 2016, 26, 940-956. [CrossRef] [PubMed]

36. Johnson, L.R.; Handel, S.N. Management intensity steers the long-term fate of ecological restoration in urban woodlands. Urban For. Urban Green. 2019, 41, 85-92. [CrossRef]

37. Hopfensperger, K.N.; Boyce, R.L.; Schenk, D. Potential reinvasion of Lonicera macckii after urban riparian forest restoration. Ecol. Restor. 2019, 37, 25-33. [CrossRef]

38. Dybala, K.E.; Steger, K.; Walsh, R.G.; Smart, D.R.; Gardali, T.; Seavy, N.E. Optimizing carbon storage and biodiversity co-benefits in reforested riparian zones. J. Appl. Ecol. 2019, 56, 343-353. [CrossRef]

39. Oldfield, E.E.; Warren, R.J.; Felson, A.J.; Bradford, M.A. FORUM: Challenges and future directions in urban afforestation. J. Appl. Ecol. 2013, 50, 1169-1177. [CrossRef]

40. US Census Bureau. QuickFacts, Lexington-Fayette, Kentucky. 2019. Available online: https://www.census.gov/quickfacts/ lexingtonfayettekentucky (accessed on 30 December 2020).

41. Lexington-Fayette Urban County Government. "Reforest the Bluegrass at Home". Available online: https://www.lexingtonky. gov / reforest (accessed on 15 January 2021).

42. Soil and Plant Analysis Council. Soil and Plant Analysis Council. Soil pH, and exchangeable acidity and aluminum. In Soil Analysis Handbook of Reference Methods; CRC Press: Boca Raton, FL, USA, 2000; Chapter 3. 
43. Soil and Plant Analysis Council. Phosphorus. In Soil Analysis Handbook of Reference Methods; CRC Press: Boca Raton, FL, USA, 2000; Chapter 6.

44. Soil and Plant Analysis Council. Major cations (potassium, calcium, magnesium, and sodium). In Soil Analysis Handbook of Reference Methods; CRC Press: Boca Raton, FL, USA, 2000; Chapter 7.

45. Miller, W.P.; Miller, D.M. A micro-pipette method for soil mechanical analysis. Commun. Soil Sci. Plant Anal. 1987, 18, 1-15. [CrossRef]

46. Burt, R.; Reinsch, T.G.; Miller, W.P. A micro-pipette method for water dispersible clay. Commun. Soil Sci. Plant Anal. 1993, 24, 2531-2544. [CrossRef]

47. Nelson, D.W.; Sommers, L.E. Total carbon, organic carbon, and organic matter. In Methods of Soil Analysis, Part 2. Chemical and Microbiological Properties, 2nd ed.; Page, A.L., Miller, R.H., Keeney, D.R., Eds.; ASA-SSSA: Madison, WI, USA, 1982.

48. R Core Team. R: A Language and Environment for Statistical Computing; R Foundation for Statistical Computing: Vienna, Austria, 2020.

49. Chojnacky, D.C.; Heath, L.S.; Jenkins, J.C. Updated generalized biomass equations for North American tree species. Forestry 2013, 87, 129-151. [CrossRef]

50. Rennolls, K. “Top Height”; its definition and estimation. Commonw. For. Rev. 1978, 57, 215-219.

51. Barton, K. MuMIn: Multi-Model Inference. R Package Version 1.43.17. 2020. Available online: https:/ /CRAN.R-project.org/ package=MuMIn (accessed on 25 February 2021).

52. Jacobs, S.L.; Hackworth, Z.J.; Comer, K.; Wittenbraker, W.; Maugans, J.J.; Jensen, K.L.; Sena, K.L. Species, DBH, and Height of Overstory Trees in a Chronosequence of Reforested Urban Sites, Lexington, KY, USA. Ver 1. Environmental Data Initiative. 2021. Available online: https:/ / doi.org/10.6073/pasta/f22406ee858daeb0b8bf3e6f4ed2ba00 (accessed on 19 March 2021).

53. Jacobs, S.L.; Hackworth, Z.J.; Comer, K.; Wittenbraker, W.; Maugans, J.J.; Jensen, K.L.; Sena, K.L. Species and Height of Understory Trees and Shrubs in a Chronosequence of Reforested Urban Sites, Lexington, KY USA. Ver 1. Environmental Data Initiative. 2021. Available online: https://doi.org/10.6073/pasta/fdcb15813501becc1ce898972a19378a (accessed on 16 April 2021).

54. Jacobs, S.L.; Hackworth, Z.J.; Comer, K.; Wittenbraker, W.; Maugans, J.J.; Jensen, K.L.; Sena, K.L. Chemical and Physical Characteristics of Soil Samples Collected from a Chronosequence of Reforested Urban Sites in Lexington, KY USA. Ver 1. Environmental Data Initiative. 2021. Available online: https://doi.org/10.6073/pasta/247c204871488a6ba981386fc3731559 (accessed on 16 April 2021).

55. Oliver, C.D. Forest development in North America following major disturbances. For. Ecol. Manag. 1980, 3, 153-168. [CrossRef]

56. Skovsgaard, J.P.; Vanclay, J.K. Forest site productivity: A review of the evolution of dendrometric concepts for even-aged stands. Forestry 2008, 81, 13-31. [CrossRef]

57. Vanclay, J.K. Tree diameter, height and stocking in even-aged forests. Ann. For. Sci. 2009, 66, 702. [CrossRef]

58. Herms, D.A.; McCullough, D.G. Emerald Ash Borer Invasion of North America: History, Biology, Ecology, Impacts, and Management. Annu. Rev. Èntomol. 2014, 59, 13-30. [CrossRef]

59. Jacobs, D.F.; Ross-Davis, A.L.; Davis, A.S. Establishment success of conservation tree plantations in relation to silvicultural practices in Indiana, USA. New For. 2004, 28, 23-36. [CrossRef]

60. Burns, R.M.; Barbara, H. Honkala, technical coordinators. In Silvics of North America: Volume 2. Hardwoods; Agriculture Handbook 654; USDA Forest Service: Washington, DC, USA, 1990.

61. Stanturf, J.; Schweitzer, C.; Gardiner, E. Afforestation of marginal agricultural land in the Lower Mississippi River Alluvial Valley, USA. Silva Fenn. 1998, 32, 281-297. [CrossRef]

62. Dey, D.C.; Gardiner, E.S.; Kabrick, J.M.; Stanturf, J.A.; Jacobs, D.F. Innovations in afforestation of agricultural bottomlands to restore native forests in the eastern USA. Scand. J. For. Res. 2010, 25, 31-42. [CrossRef]

63. Steele, K.L.; Kabrick, J.M.; Dey, D.C.; Jensen, R.G. Restoring Riparian Forests in the Missouri Ozarks. North. J. Appl. For. 2013, 30, 109-117. [CrossRef] 